\title{
Pengelompokan Sekolah Dasar Di Siau berdasarkan Indikator Mutu Sekolah dengan Menggunakan Analisis Gerombol
}

\author{
Melysa Matahari ${ }^{1}$, John S. Kekenusa ${ }^{2}$, Yohanes A.R. Langi ${ }^{3}$ \\ ${ }^{1}$ Program Studi Matematika, FMIPA, UNSRAT Manado, melysamatahari@ yahoo.co.id \\ ${ }^{2}$ Program Studi Matematika, FMIPA, UNSRAT Manado, johnskekenusa @ yahoo.com \\ ${ }^{3}$ Program Studi Matematika, FMIPA, UNSRAT Manado, yarlangi@gmail.com
}

\begin{abstract}
Abstrak
Tujuan penelitian ini adalah: mengelompokan sekolah-sekolah dasar yang ada di siau berdasarkan indikator mutu sekolah dengan menggunakan analisis gerombol. Data Penelitian ini adalah data primer yang diperoleh dari 15 Sekolah Dasar (SD) di Kabupaten SITARO.Analisis Gerombol merupakan Analisis Statistik yang digunakan untuk mengelompokkan $\mathrm{n}$ objek pengamatan ke dalam $\mathrm{k}$ buah kelompok dimana anggotaanggotanya memiliki karakteristik yang serupa dalam satu atau lebih dari satu gerombol Hasilnya menunjukkan bahwa, terbentuk tiga kelompok atau gerombol yaitu anggota kelompok pertama adalah SD Nasaret Niambangeng, SD Kinali, SD Pniel Kawahang, SD Bethabara Paseng, SD Baitesda Bumbiha, SD Eirene Hiung dan SD Khatolik Ondong dengan indikator mutu yang unggul adalah nilai rata-rata HUN, kondisi bangunan sekolah, banyaknya jenis ruangan, Jumlah eksemplar buku pegangan siswa terhadap jumlah siswa per mata pelajaran, Jumlah eksempalar buku pegangan guru permata pelajaran, rasio jumlah siswa terhadap guru, dan rasio jumlah pendaftaran terhadap jumlah yang diterima. Anggota kelompok kedua adalah SD Lehi, SD Mini dan SD Inpres Pehe dengan indikator mutu yang unggul adalah nilai rata-rata HUN, kondisi bangunan sekolah dan banyaknya jenis ruangan. Anggota kelompok ketiga adalah SD Immanuel Ondong, SD Inpres Peling, SD Inpres Paniki, SD Bukide dan SD Nayarmon Nameng dengan indikator mutu sekolah yang unggul adalah jumlah perlengkapan sekolah.
\end{abstract}

Kata kunci: Analisis Gerombol, Indikator Mutu Sekolah

\section{Clustering of Elementary Schools in Siau based on School Quality Indicators using Clustering Analysis}

\begin{abstract}
The purpose of this study is: classifying elementary schools in Siau based indicators of school quality by using analysis cluster. This study obtained data from 15 elementary schools (SD) in Sitaro District.The results show that, formed three groups or clump that is members of the first group there are SD Nazareth Niambangeng, SD Kinali, SD Pniel Kawahang, SD Bethabara Paseng, SD Baitesda Bumbiha, SD Eirene Hiung and SD Catholic Ondong with superior quality indicator is average value HUN, School Buildings Condition, many types of rooms, number of copies Students Handbook per Subjects, number of Copies Teacher Handbook per Subject, Student ratio to Teacher and Amount Ratio of Registration and Received. Members of the second group are SD Lehi, SD Mini and SD Inpres Pehe with superior quality indicator is average value HUN, School Buildings Condition and the many types of room. Members of the third group are SD Immanuel Ondong, SD Presidential Peling, SD Presidential Paniki, SD Bukide and SD Nayarmon Nameng with a superior indicator of school quality is the amount of school equipment.
\end{abstract}

Keywords: Cluster Analysis, Quality Indicators of School

\section{Pendahuluan}

Sekolah dasar (SD) adalah jejang pendidikan paling dasar pada pendidikan formal di Indonesia. Sekolah Dasar merupakan jenjang pendidikan yang paling penting keberadaannya karena proses awal dimulainya seseorang dalam menempuh dunia pendidikan. Siswa tidak dapat melanjutkan pendidikannya ke SMP dan SLTA tanpa menyelesaikan pendidikan di jenjang Sekolah Dasar. Karena.lembaga SD merupakan peletak dasar di bidang pendidikan, maka dalam memilih lembaga ini kebanyakan orang tua memperhatikan mutu atau kualitas sekolah . 
Mengingat sangat pentingya pendidikan maka diperlukan lembaga pendidikan yang bermutu/berkualitas baik. Maka dari itu melalui penelitian ini akan dilakukan pengelompokkan SD yang ada di Siau berdasarkan indikator mutu sekolah menggunakan analisis gerombol. Analisis gerombol merupakan salah satu bagian dari analisis peubah ganda (APG) yang digunakan untuk mengelompokan objek kedalam beberapa kelompok berdasarkan kesamaan objek-objek tersebut.

Tujuan penelitian ini yaitu mengelompokkan sekolah-sekolah dasar yang ada di Siau berdasarkan Indikator Mutu sekolah.

\section{Mutu Sekolah}

Mutu merupakan jaminan dari sebuah lembaga kepada pelanggannya. Pelangganlah yang akan menentukan apakah lembaga tersebut mutu produknya (barang atau jasa) baik atau buruk, arena mereka adalah raja yang dapat memilih dan menentukan barang mana yang akan dibeli atau dimanfaatkan. Dalam konteks pendidikan pengertian mutu mengacu pada proses pendidikan dan hasil pendidikan. Dalam "proses pendidikan" yang bermutu terlibat berbagai input, seperti; bahan ajar (kognitif, afektif, atau psikomotorik), metodologi (bervariasi sesuai kemampuan guru), dukungan administrasi dan sarana prasarana dan sumber daya lainnya serta penciptaan suasana yang kondusif [1].

\section{Normalitas}

Uji normalitas bertujuan untuk menguji apakah suatu variabel mempunyai distribusi normal atau tidak. Salah satu cara untuk melihat kenormalan data yaitu dengan uji KolmogorovSmirnov[2].

Pengujian dilakukan dengan membandingan probabilitas tingkat signifikan, hasil dengan tingkat signifikan yang ditetapkan $(\alpha)$. Tingkat $\alpha$ yang digunakan biasanya 5\%. Distribusi data dinyatakan normal, apabila setiap variable yang dianalisis mempunyai nilai signifikan lebih dari $5 \%(0,05)[3]$.

Hipotesis yang diuji adalah :

$H_{0}$ : data berdistribusi normal

$H_{1}$ : data tidak berdistribusi normal

Terima $H_{0}$ apabila $p$-value $>\alpha$, dan tolak $H_{0}$ apabila $p$-value $<\alpha$.

\section{Analisis Gerombol}

Cluster atau gerombol dapat diartikan sebagai kelompok dengan demikian pada dasarnya analisis gerombol akan menghasilkan sejumlah gerombol (kelompok). Analisis ini diawali dengan pemahaman bahwa sejumlah data tertentu sebenarnya mempunyai kemiripan di antara anggotanya; karena itu, dimungkinkan untuk mengelompokan anggota-anggota yang 'mirip' atau mempunyai karakteristik yang serupa tersebut dalam satu atau lebih dari satu gerombol [4].

Analisis gerombol melakukan sebuah usaha untuk menggabungkan keadaan atau objek ke dalam suatu kelompok, dimana anggota kelompok itu tidak diketahui sebelumnya untuk dianalisis. Dengan kata lain analisis gerombol merupakan analisis statistik yang digunakan untuk mengelompokan $\mathrm{n}$ objek ke dalam $\mathrm{k}$ buah kelompok, dengan setiap objek dalam kelompok memiliki keragaman yang besar dibandingkan antar kelompok [4].

Analisis gerombol merupakan salah satu teknik multivariat metode interdependensi (saling ketergantungan). Oleh karena itu, dalam analisis gerombol tidak ada pembedaan antara variabel bebas (independent variable) dan variabel terikat (dependent variable) [4].

Dalam analisis gerombol, terdapat banyak metode untuk mengelompokkan observasi ke dalam gerombol. Secara umum metode pengelompokan dalam analisis gerombol dibedakan menjadi hirarki (Hierarchical Clustering Method) dan metode non hirarki (Nonhierarchical Clustering Method). Metode hirarki digunakan apabila belum ada informasi jumlah gerombol yang dipilih. Sedangkan metode non hirarki bertujuan untuk mengelompokkan objek ke dalam kgerombol $(k<n)$, di mana nilai $k$ telah ditentukan sebelumnya [4]. 
Metode analisis gerombol membutuhkan suatu ukuran ketakmiripan (jarak) yang didefinisikan untuk setiap pasang objek yang akan dikelompokan. Jarak yang biasa digunakan dalam analisis penggerombolan diantaranya :

1. Jarak Euclidean

Jarak ini merupakan tipe jarak yang paling umum dipilih. Kemudahannya adalah jarak geometri dalam ruang dimensi ganda dengan perhitungannya sebagai berikut :

$$
\operatorname{jarak}(x, y)=\sqrt{\sum_{i}\left(x_{i}-y_{i}\right)^{2}}
$$

Jarak Euclidean biasanya dihitung dari data mentah, dan tidak dari data standar. Metode ini memiliki beberapa keuntungan, antara lain jarak dari 2 objek apa saja tidak dipengaruhi oleh penambahan dari objek baru untuk dianalisis yang mungkin merupakan pencilan.

2. Jarak Kuadrat Euclidean

Mengkuadratkan jarak Euclidean standar untuk menempatkan bobot yang lebih besar secara progresif pada objek yang jaraknya jauh dengan cara perhitungannya :

$$
(x, y)=\sum_{i}\left(x_{i}-y_{i}\right)^{2}
$$

Keterangan : $x_{i}=$ pengamatan, $y_{i}=$ kordinat rataan

3. Jarak Chebychev

Ukuran jarak ini mungkin cocok untuk khasus menentukan 2 objek,sebagai "Berbeda" jika mereka berbeda terhadap segala sesuatu pada dimensi. Perhitungannya :

$$
\text { jarak }(x, y)=\operatorname{maksimum}\left|x_{i} y_{i}\right| \quad[5] \text {. }
$$

\section{Metode Penggerombolan Hierarki}

Metode ini digunakan untuk menggerombolkan pengamatan secara terstruktur berdasarkan kemiripan sifatnya dan grombol yang diinginkan belum diketahui banyaknya. Ada dua cara untuk mendapatkan gerombol dengan metode penggrombolan hierarki yaitu dengan cara penggabungan dan pemisahan gerombol. Metode hierarki dengan cara penggabungan didapat dengan menggabungkan pengamatan atau gerombol secara bertahap, sehinnga pada akhirnya didapat hanya satu gerombol saja. Sebaliknya cara pemisahan dimulai dengan membentuk satu gerombol besar beranggotakan seluruh pengamatan. Gerombol besar tersebut kemudian dipisah menjadi gerombol yang lebih kecil, sampai satu gerombol beranggotakan satu pengamatan saja [6].

\section{Metode Penggerombolan Non-Hierarki}

Salah metode dalam metode penggerombolan tak berhirarki yaitu metode $k$-means. Algoritma dari metode ini sebagai berikut pertama tetntukan besarnya $k$ (yaitu banyaknya gerombol dan tentukan juga centroid di tiap gerombol), kedua hitung jarak antara setiap objek dengan setiap centroid, ketiga hitung kembali rataan (centroid) untuk gerombol yang baru terbentuk dan keempat ulangi langkah 2 sampai tidak ada lagi pemindahan objek antar gerombol [5]

Mac-Queen menyarankan penggunaan K-rataan untuk menjelaskan algoritma dalam penentuan suatu objek ke dalam gerombol tertentu berdasarkan rataan terdekat. Dalam bentuk yang paling sederhana, proses ini terdiri dari tiga tahap :

1. Bagi objek-objek tersebut ke dalam $\mathrm{K}$ gerombol awal.

2. Masukkan tiap objek ke suatu gerombol berdasarkan rataan terdekat. Jarak biasanya ditentukan dengan menggunakan jarak Euclidean. Hitung kembali rataan untuk gerombol yang mendapat objek danyang kehilangan objek.

3. Ulangi langkah 2 sampai tidak ada lagi pemindaan objek antara gerombol.

\section{Metodologi Penelitian}

\subsection{Waktu dan Tempat Penelitian}

Penelitian dilaksanakan pada bulan Maret sampai bulan April 2015 di Siau Kab.SITARO. 


\subsection{Jenis dan Sumber Data}

Data yang digunakan adalah data primer, dimana peneliti akan turun langsung ke tiap-tiap sekolah dasar untuk melakukan pengambilan data sesuai dengan variabel yang dibutuhkan. Teknik pengambilan sampel diambil secara sengaja atau proposive sample. Adapun sekolah yang dikunjungi untuk pengambilan data ada 15 sekolah dasar dari 52 sekolah dasar yang ada di Siau, mulai dari sekolah yang tidak bisa dilalui kendaraan roda 4 sampai sekolah daerah perkotaan. Sekolah dasar yang terletak pada daerah terpencil diantaranya SD Bukide, SD Nayarmon Nameng, SD Nasaret Niambangeng dan SD Kinali. Sekolah dasar yang terletak di daerah pertengahan diantaranya SD Pniel Kawahang, SD Eirene Hiung, SD Lehi dan SD Mini. Sekolah dasar yang terletak di daerah kota diantaranya SD Inpres Pehe,SD Khatolik Ondong, SD Immanuel Ondong, SD Inpres Paniki, SD Bethabara Paseng, SD Baitesda Bumbiha dan SD Inpres Peling.

\subsection{Variabel Penelitian}

Variabel-variabel yang digunakan dalam mengelompokkan Sekolah Dasar berdasarkan indikator mutu sekolah terdiri dari 10 variabel yaitu :

$X_{I}=$ Nilai rata-rata HUN

$X_{2}=$ Kondisi bangunan Sekolah (skala likert $1-5$ )

$X_{3}=$ Banyaknya jenis ruangan ( mis: perpustakaan, ruang guru, kelas dll)

$X_{4}=$ Banyaknya perlengkapan sekolah (mis: komputer, papan tulis dll)

$X_{5}=$ Jumlah eksemplar buku pegangan siswa terhadap jumlah siswa dan mata pelajaran

$X_{6}=$ Jumlah eksempalar buku pegangan guru permata pelajaran

$X_{7}=$ Rasio jumlah siswa terhadap terhadap Guru

$X_{8}=$ Rasio jumlah pendaftaran terhadap jumlah yang diterima

\subsection{Metode Analisis}

Langkah-langkah dalam analisis data :

1. Analisis Korelasi

Data asal akan dilakukan pengujian dengan menggunakan analisis korelasi, dimana untuk melihat besar kecilnya hubungan dari tiap variabel. Jika analisis korelasi sama dengan nol pada variabel-variabel yang ada maka akan dilanjutkan dengan pemeriksaan kenormalan dan langsung ke analisis gerombol.

2. Pemeriksaan Kenormalan

Selanjutnya akan dilakukan uji kenormalan pada tiap-tiap variabel. Jika data tidak berdistribusi normal maka akan dilakukan transformasi data.

3. Analisis Komponen Utama

Jika data asal yang dilakukan pengujian korelasi dan korelasinya tidak sama dengan nol atau tiap variabel yang ada memiliki hubungan dan data juga telah diperiksa kenormalannya maka selanjutnya akan dilakukan analisis komponen utama.

4. Analisis gerombol Data asal yang telah selanjutnya akan dilakukan analisis terakhir yaitu analisis gerombol untuk melihat pengelompokan yang ada.

\section{Hasil dan Pembahasan}

\subsection{Uji Kenormalan pada Tiap Variabel}

Uji Kenormalan digunakan untuk memeriksa kenormalan pada tiap variabel dari $X_{1}, X_{2}, \ldots X_{8}$. Dengan tingkat $\alpha$ yang digunakan yaitu 5\% (0.05). Pengujian normalitas data pada variabelvariabel ini menggunakan pengujian Kolmogorov-Smirnov, dengan hipotesis sebagai berikut :

$H_{0}$ : data berdistribusi normal

$H_{l}$ : data tidak berdistribusi normal 
Pengujian normalitas pada gambar 1 didapat beberapa nilai diantaranya mean sebesar 7,332, standard deviasi sebesar 0,3605, jumlah pengamatan (N) sebesar 15, Kolmogorov Smirnov sebesar 0,162 dan $p$-value sebesar 0,150 (>0.05), maka dapat disimpulkan bahwa $X_{l}$ (nilai rata-rata HUN Sekolah Dasar) berdistribusi normal.

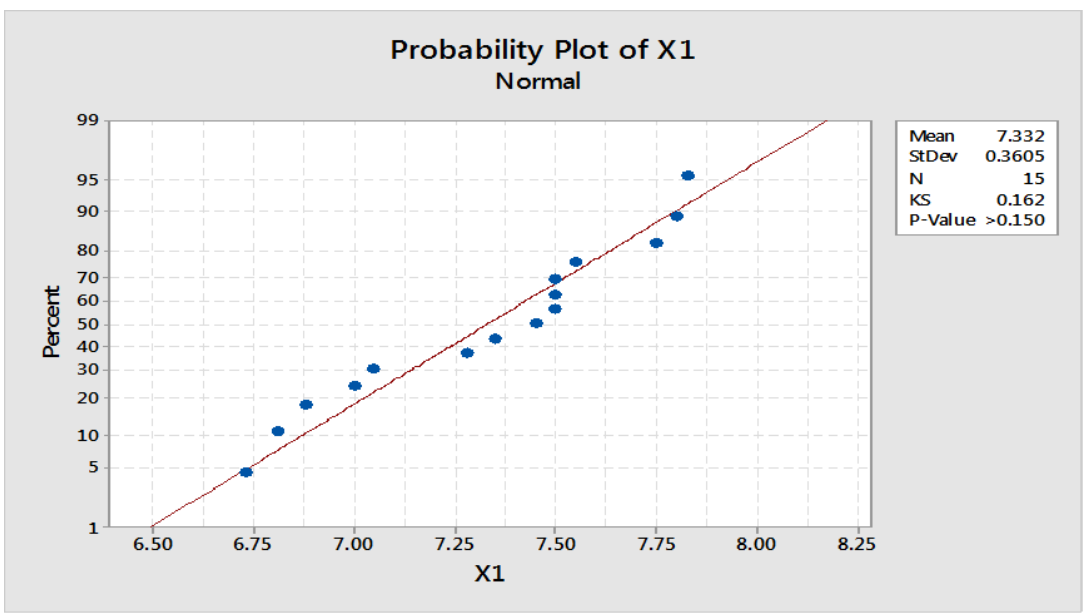

Gambar 1. Kenormalan Data $\mathrm{X}_{1}$ ( Nilai rata - rata HUN)

Pengujian normalitas pada gambar 2 didapat beberapa nilai diantaranya mean sebesar 2,867, standard deviasi sebesar 0,7432, jumlah pengamatan (N) sebesar 15, Kolmogorov Smirnov sebesar 0,238 dan $p$-value sebesar 0,031 $(<0,05)$, maka dapat disimpulkan bahwa $X_{2}$ (Kondisi bangunan sekolah) tidak berdistribusi normal.

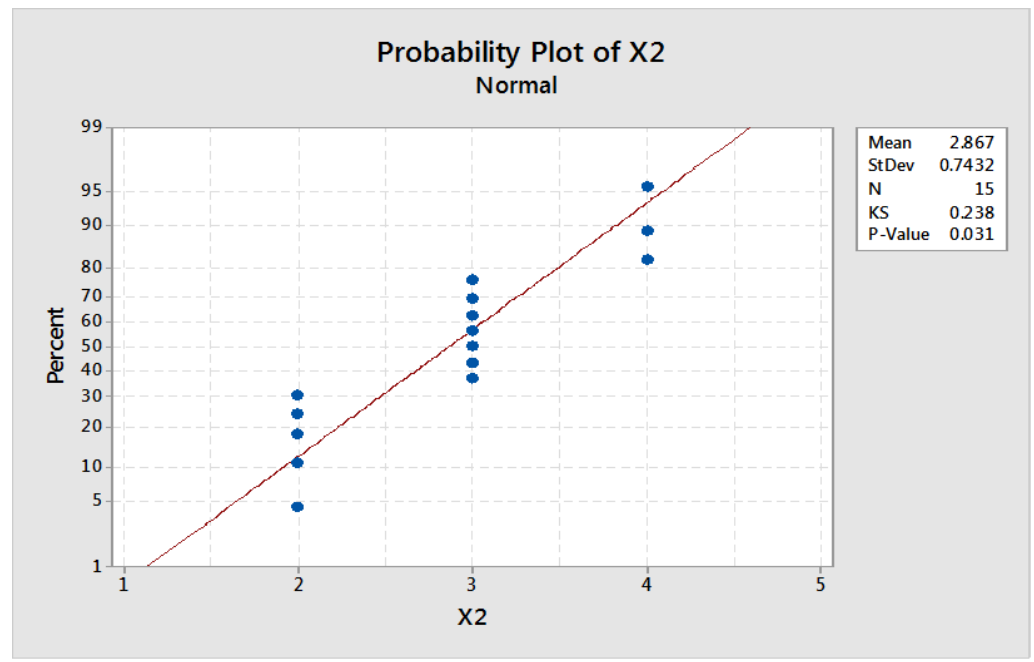

Gambar 2. Kenormalan Data $\mathrm{X}_{2}$ (Kondisi bangunan Sekolah )

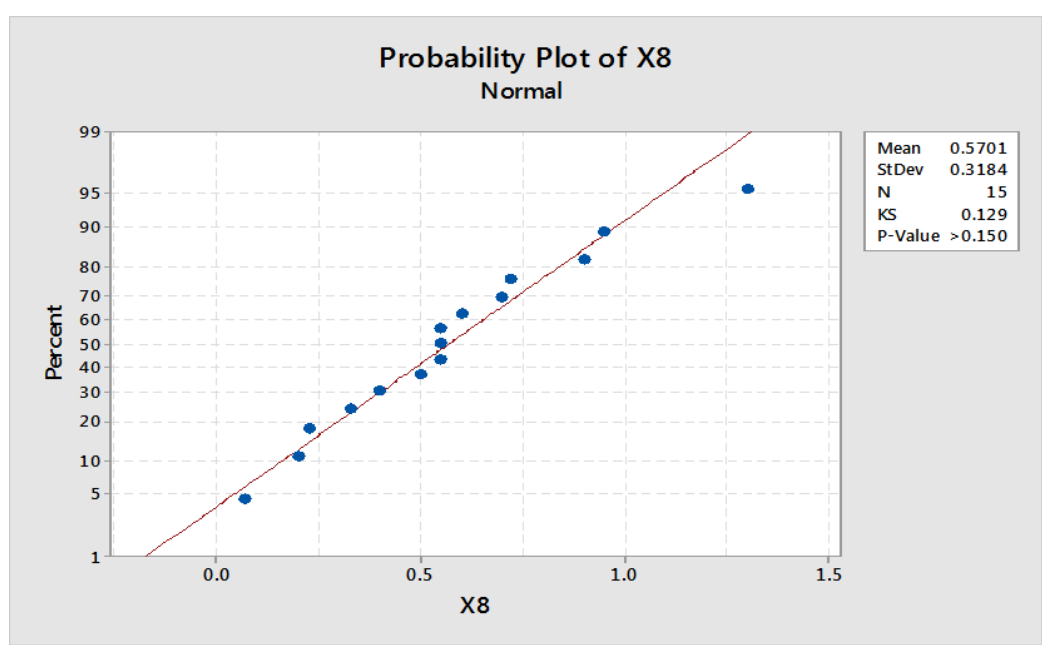

Gambar 3. Kenormalan Data $\mathrm{X}_{8}$ (Rasio jumlah pendaftaran terhadap jumlah yang diterima). 
Pada gambar 2 menunjukkan bahwa data tersebut tidak berdistribusi normal maka dilakukan transformasi data untuk menormalkan data. Namun setelah data pada variabel $\mathrm{X}_{2}$ ini dilakukan tranformasi data, data tersebut tetap juga tidak berdistribusi normal. Adapun data pada variabel $\mathrm{X}_{2}, \mathrm{X}_{3}, \ldots \mathrm{X}_{7}$ juga tidak berdistribusi normal walaupun sudah dilakukan transformasi data.

Pengujian normalitas pada gambar 3 didapat beberapa nilai diantaranya mean sebesar 0,5701, standard deviasi sebesar 0,3184, jumlah pengamatan (N) sebesar 15, Kolmogorov Smirnov sebesar 0,129 dan p-value sebesar 0,150 ( > 0,05), maka dapat disimpulkan bahwa $X_{8}$ (Rasio jumlah pendaftaran terhadap jumlah yang diterima) berdistribusi normal.

\subsection{Memperpadat Variabel Data Menggunakan Analisis Komponen Utama}

Pada data indikator mutu sekolah terdapat 8 variabel yang diambil, yaitu : $X_{1}=$ Nilai rata-rata HUN

$X_{2}=$ Kondisi bangunan Sekolah (skala liker $1-5$ )

$X_{3}=$ Banyaknya jenis ruangan ( mis: perpustakaan, ruang guru, kelas dll)

$X_{4}=$ Banyaknya perlengkapan sekolah (mis: komputer, papan tulis dll)

$X_{5}=$ Rasio jumlah eksemplar buku pegangan siswa per mata pelajaran

$X_{6}=$ Rasio jumlah eksemplar buku pegangan guru permata pelajaran

$X_{7}=$ Rasio jumlah siswa terhadap Guru

$X_{8}=$ Rasio jumlah pendaftaran terhadap jumlah yang diterima

Kedelapan variabel tersebut akan diperpadat atau akan dibuat variabel baru dengan jumlah yang lebih kecil untuk mengantikan variabel semula tanpa menghilangkan banyak informasi.

Hasil dari analisis komponen utama didapat 8 komponen utama dimana eigenvalue untuk komponen utama pertama (PC1) adalah 4,1769, eigenvalue untuk komponen utama kedua (PC1) adalah 1,4563 dann eigenvalue untuk komponen utama ketiga adalah 0,9771. Komponen utama pertama (PC1) mewakili 52,2\%, komponen utama kedua mewakili 18,2\% dan komponen utama ketiga mewakili $12,2 \%$ dari seluruh variabilitas. Bila diakumulasikan, ketiga komponen utama diperoleh $82,6 \%$ dari total variabilitas sehinggah apabila delapan variabel direduksi menjadi 3 variabel maka ketiga variabel baru tersebut dapat menjelaskan $82,6 \%$ dari total variabilitas delapan variabel. Demikian juga penjelasan pada eigenvalue komponen utama selanjutnya. Skor dari tiap komponen utama juga terlihat dalam hasil analisis, dimana menunjukkan 8 komponen utama. Sehinggah dapat ditulis (persamaan):

$$
Y_{1}=-0,338 X_{1}-0,422 X_{2}+0,341 X_{3}+0,422 X_{4}+0,250 X_{5}+0,391 X_{6}-0,331 X_{7}+0,297 X_{8} .
$$

Sama halnya untuk penulisan PC2, PC3 sampai dengan PC8.

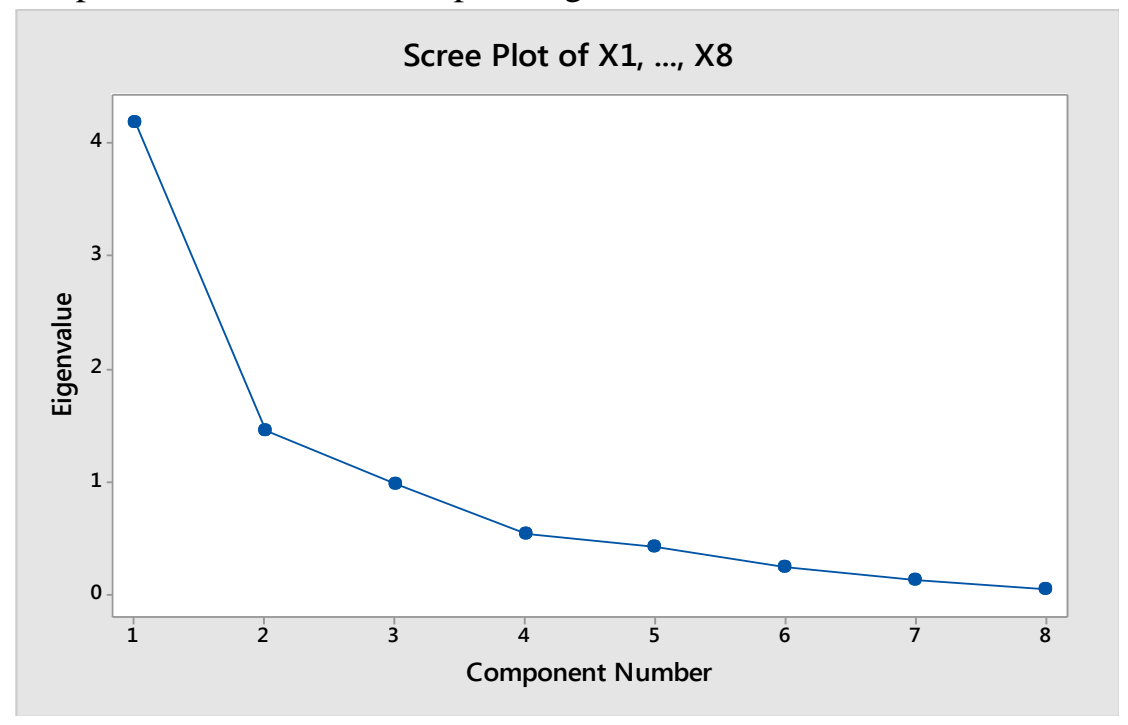

Gambar 4. Plot data untuk Analisis Komponen Utama

Gambar 4 menunjukkan hubungan antara eigenvalue dengan PC1 sampai dengan PC8. 
Gambar 5 menunjukkan hubungan antara komponen 1 dan komponen 2, yang terdiri dari 4 kuadran. Pada kuadran I ada SD Immanuel Ondong, SD Bukide dan SD Inpres Paniki. Pada kuadran II ada SD Pniel Kawahang, SD Kinali, SD Khatolik Ondong dan SD Nasaret Niambangeng. Pada kuadran III ada SD Mini, SD Lehi, SD Inpres Pehe, SD Bethabara Paseng, SD Baitesda Bumbiha dan SD Eirene Hiung. Pada kuadran IV ada SD Inpres Peling dan SD Nayarmon Nameng.

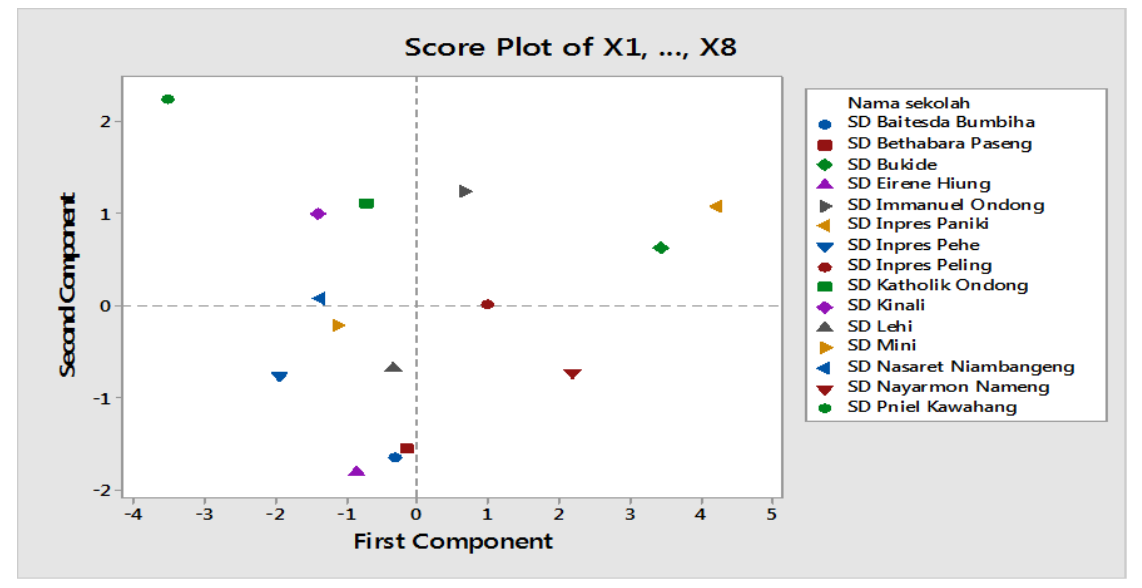

Gambar 5. Plot Data Analisis Komponen Utama

\subsection{Pengelompokan Sekolah Dasar Menggunakan Analisis Gerombol}

Output analisis gerombol dalam bentuk dendogram menunjukkan adanya 14 kelompok. Apabila hasil pengolahan data akan dibuat 3 kelompok maka dapat dibuat garis pemotong pada nilai kesamaan 99.97\%. Dimana anggota kelompok pertama adalah SD Nasaret Niambangeng, SD Kinali, SD Pniel Kawahang, SD Bethabara Paseng, SD Baitesda Bumbiha, SD Eirene Hiung dan SD Khatolik Ondong. Anggota kelompok kedua adalah SD Lehi, SD Mini dan SD Inpres Pehe. Anggota kelompok ketiga adalah SD Immanuel Ondong, SD Inpres Peling, SD Inpres Paniki, SD Bukide dan SD Nayarmon Nameng.

Jika gambar 5 dibandingkan dengan gambar 6, maka dapat dilihat pada gambar 5 sudah mulai menjelaskan pengelompokan sekolah-sekolah dasar yang ada pada kuadran I adalah SD Immanuel Ondong, SD Bukide dan SD Inpres Paniki. Pada kuadran II adalah SD Pniel Kawahang, SD Kinali, SD Khatolik Ondong dan SD Nasaret Niambangeng. Pada kuadran III adalah SD Mini, SD Lehi, SD Inpres Pehe, SD Bethabara Paseng, SD Baitesda Bumbiha dan SD Eirene Hiung. Pada kuadran IV adalah SD Inpres Peling dan SD Nayarmon Nameng. Sedangkan pada gambar 12 diperoleh 3 kelompok, dimana kelompok pertama terletak di kuadran II dan kuadran III pada gambar 5, kelompok kedua terletak di kuadran III dan pada kelompok ketiga terletak di kuadran I dan IV.

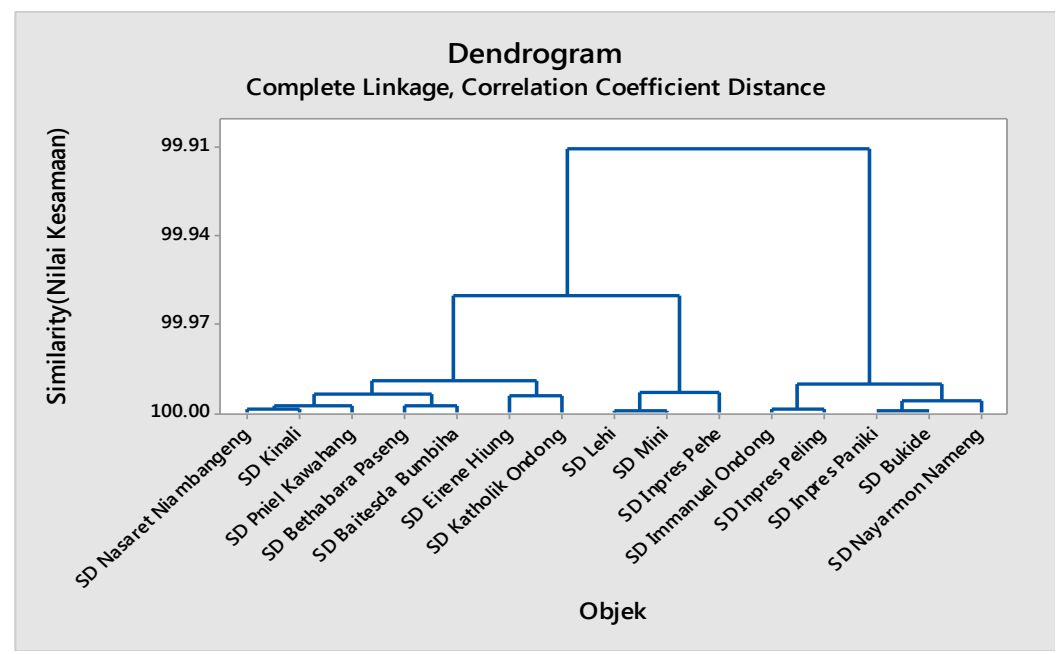

Gambar 6. Dendogram Analisis Gerombol 


\section{Kesimpulan}

Hasil pengelompokkan sekolah-sekolah dasar berdasarkan indikator mutu sekolah dengan menggunakan analisis gerombol terbentuk tiga kelompok atau gerombol. Anggota kelompok pertama adalah SD Nasaret Niambangeng, SD Kinali, SD Pniel Kawahang, SD Bethabara Paseng, SD Baitesda Bumbiha, SD Eirene Hiung dan SD Khatolik Ondong dengan indikator mutu yang unggul adalah nilai rata-rata HUN, kondisi bangunan sekolah, banyaknya jenis ruangan, Jumlah eksemplar buku pegangan siswa terhadap jumlah siswa per mata pelajaran, Jumlah eksempalar buku pegangan guru permata pelajaran, rasio jumlah siswa terhadap guru, dan rasio jumlah pendaftaran terhadap jumlah yang diterima. Anggota kelompok kedua adalah SD Lehi, SD Mini dan SD Inpres Pehe dengan indikator mutu yang unggul adalah nilai rata-rata HUN, kondisi bangunan sekolah dan banyaknya jenis ruangan. Anggota kelompok ketiga adalah SD Immanuel Ondong, SD Inpres Peling, SD Inpres Paniki, SD Bukide dan SD Nayarmon Nameng dengan indikator mutu sekolah yang unggul adalah jumlah perlengkapan sekolah.

\section{DaftarPustaka}

[1] Sangganagara, H. 2013. Konsep Pendidikan Bermutu. http://harjoko.com/2013/02/konsep-pendidikan- bermutu.html [Diakses 17 Februari 2015]

[2] Ariyoso. 2009. http://ariyoso.wordpress.com/2009/11/uji-kolmogorov-smirnor.html [Diakses 15Februari 2015]

[3] Gujarati, D. 1978. Basic Econometric. McbrawHill,Inc. New York

[4] Mattjik,A dan Sumertajaya.I. 2011. Sidik Peubah Ganda Dengan Menggunakan SAS. Bogor

[5] Hatidja, D. 2006. Analisis Peubah Ganda. Jurusab Matematika FMIPA UNSRAT Manado

[6] Safri, M. 2011. Penggelompokan Kelas Kekuatan pada beberapa Jenis Kayu berdasarkan Sifat Mekanik dengan menggunakan Analisis Gerombol. Jurnal Penelitian Sains. (12)1 : $1-5$ 